\title{
ECOLOGICAL IMPACT OF Merremia peltata (L.) Merrill INVASION ON PLANT DIVERSITY AT BUKIT BARISAN SELATAN NATIONAL PARK
}

\author{
JANI MASTER ${ }^{1} *$, SRI S. TJITROSOEDIRDJO² , IBNUL QAYIM $^{3}$, and \\ SOEKISMAN TJITROSOEDIRDJO ${ }^{2}$ \\ ${ }^{1}$ Department of Biology, Faculty of Mathematics and Natural Science, Lampung University \\ ${ }^{2}$ South East Asian Regional Center for Tropical Biology (SEAMEO BIOTROP), Bogor, Indonesia \\ ${ }^{3}$ Department of Biology, Faculty of Mathematics and Natural Science, \\ Bogor Agriculture University, Bogor, Indonesia.
}

Received 25 March 2013/Accepted 13 June 2013

\begin{abstract}
Bukit Barisan Selatan National Park (BBSNP) is the third largest protected area in Sumatra. Unfortunately, the area is now invaded by Merremia peltata or mantangan occupying about 7000 ha of the area. The aim of this study was to determine the ecological impacts of mantangan on plant species composition at BBSNP. Three sites with different disturbance regimes were selected for vegetation analysis and assessment on plant species composition : primary forest representing undisturbed area, secondary forest representing burned area, and invaded forest representing forest invaded by mantangan. Three line transects were constructed at each locations along $1 \mathrm{~km}$, and the nested sampling plots were set up every $100 \mathrm{~m}$ with the following quadrant's size: $20 \mathrm{~m}$ x $20 \mathrm{~m}$ for trees, $10 \mathrm{~m}$ x $10 \mathrm{~m}$ for poles, $5 \mathrm{~m} \times 5 \mathrm{~m}$ for sapling, and $2 \mathrm{~m} \times 2 \mathrm{~m}$ for seedling. Data collection covered the degree of mantangan invasion, trees species and diameter. Results showed that invaded forest has lower plant diversity index (1.90) than the other two forests. This was caused by the invasion of mantangan as the percentage of coverage in the invaded forest reached $44 \%$ compared to secondary and the primary forest, which were $27.11 \%$ and $1.00 \%$, respectively. Percentage of mantangan coverage and diversity showed a strong negative correlation $(-0.988)$.
\end{abstract}

Keywords: invasive species, impact, Merremia peltata, mantangan, Bukit Barisan Selatan National Park

\section{INTRODUCTION}

Bukit Barisan Selatan National Park (BBSNP) is considered as the third largest protected area in Sumatra, located at the southern tip of Sumatera island covering an area of 356800 ha, extending from the southern of Lampung province up north to Bengkulu province (BTNBBS 1999). The park also has the distinction of being

\footnotetext{
*Corresponding author : j.janter@gmail.com
} 
one of the few remaining tropical rain forests that harbors rhinos, tigers, and elephants. It is also a home for over 300 bird species, sun bears, bearded pigs, tapirs, gibbons, leaf monkey, great argus pheasants, rare orchids, Rafflessia and Amorphophallus titanum.

Presently, it was reported that BBSNP has lost more than $20 \%$ of its original forest area and it has been facing with serious threats of deforestation (Suyadi 2011). This valuable remaining forest will become highly fragmented into isolated patches if current deforestation and encroachment rates continue. Beside threatened with rapid deforestation and encroachments, this area has now been invaded by Merremia peltata or called as mantangan occupying about $7000 \mathrm{ha}$. Mantangan is a local plant species native to Asia. It has wide distribution, extending from Indian Ocean Islands of Pemba, Madagascar, Mauritius, Reunion, and the Seychelles, throughout Malesia, northern Australia and eastwards into Polynesia to the Society Islands (Smith 1991).

The mantangan invasion in BBSNP has been reportedly disturbing the natural habitat of a number of wild animals. Irianto and Tjitrosoedirdjo (2010) reported that the wild animals migrated up to the north approaching human settlements due to declining of food resources. It was argued that habitat loss and poaching impacted badly on the population of wild animals. Poaching reduced the number of tigers and rhinos in the park. Tiger and human conflicts have been increasing around the park, leading to losses on both sides (Irianto \& Tjitrosoedirdjo 2010).

Irianto and Titrosoedirdjo (2010) reported a heavy invasion of mantangan in Tambling village, an area inside the BBSNP close to the seashore; mantangan grew prolifically, the young shoot of mantangan is brown purplish in color with a leaf diameter up to $40 \mathrm{~cm}$ and yellow flower. Trees found in the area were among others Ficus sp., pule (Alstonia scholaris), jabon (Anthocepalus cadamba) and others as well as shrubs covered heavily by the climbing $M$. peltata, giving a view of mantangan invasion in the area. This study assessed the ecological impacts of mantangan invasion on plant diversity at BBSNP.

\section{MATERIALS AND METHODS}

The observation was conducted from February 2011 to January 2012. Herbarium studies were conducted in the Herbarium Bogoriense (BO), and SEAMEO BIOTROP (BIOT), Bogor, Indonesia. Sampling site for vegetation analysis was divided into three categories purposively based on invasion regimes. The first location has very little invasion of mantangan, an average of only $1 \%$. The second location has a moderate invasion ( $5 \%-50 \%$ with an average value of $27 \%$ ). The third location is the location with the highest invasion, up to $100 \%$ with an average of $44 \%$. Invasion of mantangan was calculated by estimating the percentage of the plot covered by mantangan.

The second location was a post-fire forest in 1997, fires that occur mostly on the forest floor which affect the lining of plant down and open up some of the forest canopy (WCS-IP 2001). The third location lies close to the village enclave Way Haru, Bandar Dalam and Tampang. Based on land cover maps, this site has been decreasing forest cover an area of 2565.54 ha from 2000 to 2009. Presumably these changes are 
the result of forest clearing intended for plantations (Prasetyo et al. 2011), while the first location is never disturbed. Accordingly, the first location is referred as primary forest, the second as secondary forest and the third location as invaded forest (Fig.1).

Line transects were constructed and replicated three times at each location. Each line transect was drawn from the edge of the forest up to the forest along $2 \mathrm{~km}$ in distance, and square plots were made every $100 \mathrm{~m}$. The nested sampling plots were constructed with the following measurement: $2 \times 2 \mathrm{~m}$ for seedling, $5 \times 5 \mathrm{~m}$ for sapling, $10 \times 10 \mathrm{~m}$ for poles, and $20 \times 20 \mathrm{~m}$ for trees (Fig. 2). The data collected were diameter of the trees, trees species (include poles, sapling and seedling). Computation on density, dominance, frequency and importance value indices were made from trees, pole, sapling and seedlings. Diversity index of Shannon-Wiener Diversity, evenness index and similarity index were calculated.

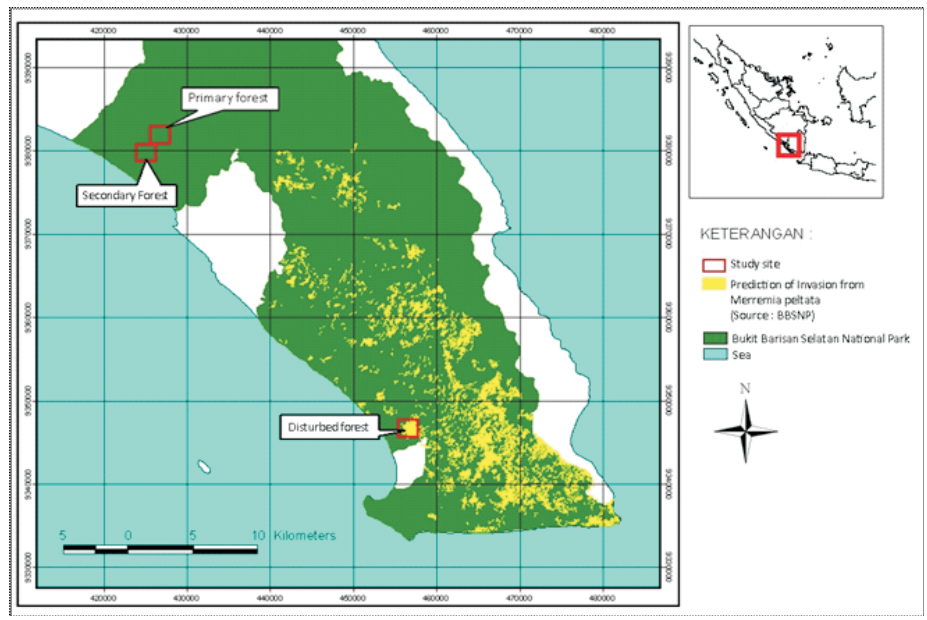

Figure 1. Map of study site

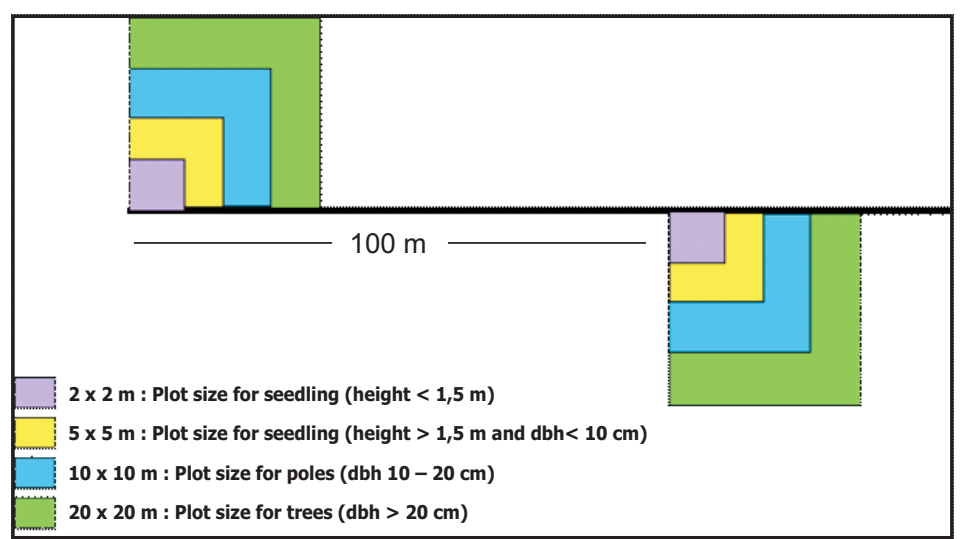

Figure 2. Plot design of the vegetation analysis 


\section{RESULTS AND DISCUSSION}

Based on vegetation analysis that was conducted on three sampling sites of 1 ha sample area, the primary forest had 153 species of trees with diameter above $10 \mathrm{~cm}$. In the secondary forest, there were 103 species of trees with diameter above $10 \mathrm{~cm}$, while the invaded forest had 116 species of trees with diameter above $10 \mathrm{~cm}$.

Based on the observation, species composition within the three sample sites was relatively high compared to a number of research findings taken from other lowland tropical rainforests. By comparison, trees with diameter above $10 \mathrm{~cm}$ within $1 \mathrm{ha}$ sample plot in Kayan Mentarang National Park, East Kalimantan had 106 species of plants (Purwaningsih 2009); in Pasoh Malaysia, there were 683 species of plants recorded from a sample area of 50 ha; in Baro Colorado Island (BCI) Panama, there were 229 plant species in a sample area of 50 ha (Condit et al. 1996); in Costa Rica, there were 561 plant species in a sample area of 23.4 ha (Lieberman et al. 1996); and in Uppangala, Ghats, India, there were 103 plant species in a sample area of 28 ha (Pascal 1996).

The tree density in primary forest indicated that the forest was still in good condition than the secondary forest and invaded forest. Tree density with diameter $>$ $10 \mathrm{~cm}$ in primary forest was 403 trees per hectare, while in secondary and invaded forests; there were 365 and 305 trees per hectare, respectively. According to Campbell et al. (1992), tree density with diameter $>10 \mathrm{~cm}$ in tropical areas was about $245-859$ trees per hectare. Meanwhile, according to Sheil et al. (2002), tree density with diameter over $10 \mathrm{~cm}$ in tropical rainforests was about 400 - 600 trees per hectare.

Invaded forests had fewer species than primary and secondary forests due to mantangan invasion. The highest percentage of mantangan coverage was in the invaded forest with an average of $44.00 \%$, followed by the secondary forest with an average of $27.11 \%$ and the primary forest as the lowest coverage with an average of $1.00 \%$. In line with the number of species' data and mantangan coverage, it can be obviously seen that the more the forest was invaded, the less the plants lived there (Fig. 3). Not only the number of species, but also the number of individuals in the invaded forest was less than in primary forest.

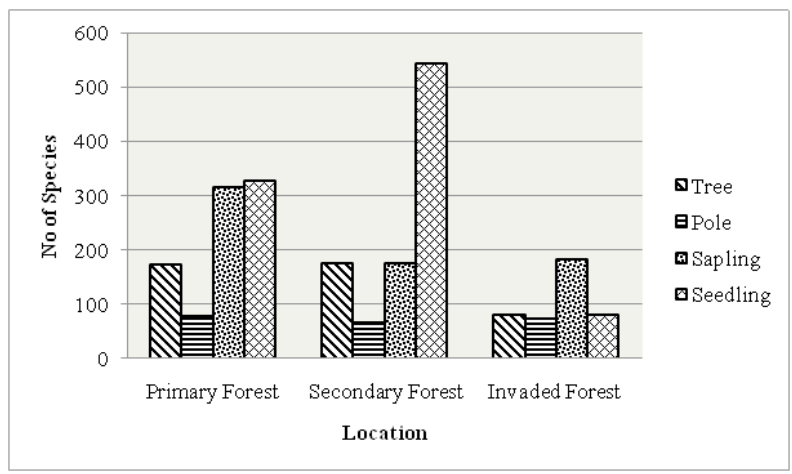

Figure 3. The number of individuals on three research sites 
Tropical rainforests had vegetation composition that illustrated the dynamics of regeneration which occurred naturally, in which the vegetation at seedling stage had the highest number of species. Furthermore, the number of species started to decrease at sapling and timber stages. However, it does not occur in the invaded forest. Figure 3 shows that the number of seedlings was significantly less than the number of saplings. Besides, the number of seedlings on this invaded forest was less than those of two other sites.

Each research site was dominated by different species, either seedling, sapling, pole, or tree. Trees of the primary forest was dominated by Strombosia javanica and Dipterocarpus palembanicus. Meanwhile, the secondary forest was dominated by Tetrameles nudifora, while the invaded forest was dominated by Cananga odorata that was a plant with the second-highest IVI on the secondary forest (Table 1). The dominant trees on the secondary and invaded forests were fast growing trees, such as $C$. odorata, T. nudiflora and Glocbidion arborescens. It indicated that the forests were ever in a disturbed condition. Moreover, another indication was vegetation of the family Datiscaceae such as T. nudiflora that could survive on burned land (Goldammer 1996).

In the invaded forest, there were still some vegetation of the family Dipterocapaceae. This was demonstrated by the presence of $D$. palembanicus as the second-highest IVI in that site. This tree showed high capability to withstand againts invasion of mantangan. In addition, there were other five members of Dipterocapaceae, for instance Dipterocarpus retusus, Shorea javanica, Anisoptera costata, and Vatica obovata.

Pole stage at the primary forest was dominated by Strombosia javanica. The species composition at this stage was similar to the tree stage. Meanwhile, secondary forest was dominated by T. nudiflora, different species with tree stage in this location. In the invaded forest, Dillinea exelsa dominate this stage. The highest IVI in the secondary forest was Bridelia monoica and Croton argyratus in the invaded forest. Furthermore, at sapling stage, the primary forest was dominated by Popowia bancana, while the secondary and invaded forests were dominated by Dillenia excelsa. The domination of $P$. bancana at sapling stage in the primary forest also occurred at seedling stage. At seedling stage Cleisthantus myrianthus dominated the secondary forest, while Aglaia macrophyla dominated the invaded forest (Table 1).

Research findings showed that plant community in the primary forest was more steady than secondary and invaded forests. Species domination at tree stage at secondary and invaded forest was not followed by other stages. This condition enables structure and species composition revolution in the future. If the dominant trees on both forests were fallen, so it would be substituted by other dominant species from the stages underneath.

In terms of Shannon-Wiener's diversity index, tree, pole and sapling in three forest types did not differ one from the other (Table 2). However, when all stages were considered, diversity in invaded forests was less than primary and secondary forests. The low diversity is negatively correlated with invasion of mantangan $(-0.988$, $\mathrm{p}$ value $=0.097)$, high invasion of mantangan led to a low diversity of plant.

Shanon-Wiener Diversity Index is calculated from numbers of species, without considering if the species which make up the number is different, when the species making the number is considered and compared each other using Index of similarity, 
BIOTROPIA Vol. 20 No. 1, 2013

Table 1 . The three highest IVI at each research site

\begin{tabular}{|c|c|c|c|c|}
\hline \multirow[b]{2}{*}{ Family } & \multirow[b]{2}{*}{ Spesies } & \multicolumn{3}{|c|}{ IVI } \\
\hline & & $\begin{array}{c}\text { Primary } \\
\text { Forest }\end{array}$ & $\begin{array}{c}\text { Secondary } \\
\text { Forest }\end{array}$ & $\begin{array}{c}\text { Invaded } \\
\text { Forest }\end{array}$ \\
\hline \multicolumn{5}{|l|}{ Tree } \\
\hline Sterculiaceae & Strombosia javanica & 31.70 & & \\
\hline Dipterocarpaceae & $\begin{array}{l}\text { Dipterocarpus } \\
\text { palembanicus }\end{array}$ & 25.11 & & $22^{\prime}, 90$ \\
\hline Anacardiaceae & Dracontomelon dao & 23.80 & & \\
\hline Datiscaceae & Tetrameles nudiflora & & 43.75 & \\
\hline Annonaceae & Cananga odorata & & 35.16 & 36.14 \\
\hline Euphorbiaceae & Glochidion arborescens & & 14.31 & 17.14 \\
\hline \multicolumn{5}{|l|}{ Pole } \\
\hline Sterculiaceae & Strombosia javanica & 33.64 & & \\
\hline Euphorbiaceae & Croton argyratus & 17.25 & & 37.82 \\
\hline Meliaceae & Aphanamixis bumile & 15.77 & & \\
\hline Euphorbiaceae & Bridelia monoica & & 34.55 & 27.59 \\
\hline Dilleniaceae & Dillenia excelsa & & 32.60 & \\
\hline Annonaceae & Cananga odorata & & 30.50 & \\
\hline Dipterocarpaceae & $\begin{array}{l}\text { Dipterocarpus } \\
\text { palembanicus }\end{array}$ & & & 22.48 \\
\hline \multicolumn{5}{|l|}{ Sapling } \\
\hline Annonaceae & Popowia bancana & 41.07 & 13.12 & \\
\hline Euphorbiaceae & Glycosmis pentaphylla & 24.90 & & \\
\hline Annonaceae & Popowia pisocarpa & 21.26 & & \\
\hline Dilleniaceae & Dillenia excelsa & & 28.41 & 39.25 \\
\hline Lauraceae & Endiandra rubescen & & 15.47 & \\
\hline Euphorbiaceae & Croton argyratus & & & 25.81 \\
\hline Euphorbiaceae & Cleisthantus myrianthus & & & 19.84 \\
\hline \multicolumn{5}{|l|}{ Seedling } \\
\hline Annonaceae & Popowia bancana & 24.61 & & \\
\hline Euphorbiaceae & Glycosmis pentaphylla & 22.58 & & \\
\hline Sterculiaceae & Pterospermum javanicum & 9.49 & & \\
\hline Euphorbiaceae & Bridelia monoica & & 10.76 & \\
\hline Euphorbiaceae & Cleisthantus myrianthus & & 35.20 & \\
\hline Sapindaceae & $\begin{array}{l}\text { Xerospermum } \\
\text { noronbianum }\end{array}$ & & 10.72 & \\
\hline Meliaceae & Aglaia macrophyla & & & 19.39 \\
\hline Euphorbiaceae & Bridelia monoica & & & 15.59 \\
\hline Dilleniaceae & Dillenia excelsa & & & 14.42 \\
\hline
\end{tabular}

they are different one from the other (Dyke 2003). According to those arguments, similarity index (IS) was calculated by using Steinhaus coefficient. Its result was low index value (close to 0 ) that means those three sites at all stages had different species composition (Table 3). Mantangan devastated the habitat by covering other plants so that it reduced the availability of light for other plants. 
Ecological Impact of Merremia peltata Invasion - Jani Master et al.

Table 2. Shannon-Wiener diversity index $\left(\mathrm{H}^{\prime}\right)$ and the average percentage of mantangan cover

\begin{tabular}{|c|c|c|c|c|c|c|}
\hline \multirow[b]{2}{*}{ Location } & \multicolumn{5}{|c|}{ Shannon-Wiener's Diversity Index $\left(\mathrm{H}^{\prime}\right)^{\mathrm{a})}$} & \multirow{2}{*}{$\begin{array}{c}\% \text { average of } \\
\text { Coverage } \\
\text { mantangan }\end{array}$} \\
\hline & Tree & Pole & $\begin{array}{c}\text { Sapling } \\
\text { (g) }\end{array}$ & $\begin{array}{c}\text { Seedling } \\
\text { (g) }\end{array}$ & All stage & \\
\hline $\begin{array}{l}\text { Primary } \\
\text { Forest }\end{array}$ & $3.84 \mathrm{a}$ & $3.61 \mathrm{a}$ & $3.51 \mathrm{a}$ & $3.51 \mathrm{a}$ & $2.49 \mathrm{a}$ & 1.00 \\
\hline $\begin{array}{l}\text { Secondary } \\
\text { Forest }\end{array}$ & $3.31 \mathrm{a}$ & $3.12 \mathrm{a}$ & $3.74 \mathrm{a}$ & $2.75 b$ & $2.21 \mathrm{~b}$ & 27.11 \\
\hline $\begin{array}{l}\text { Invaded } \\
\text { Forest }\end{array}$ & $3.46 a$ & $3.23 \mathrm{a}$ & $3.46 \mathrm{a}$ & $2.66 \mathrm{~b}$ & $1.90 \mathrm{c}$ & 44.00 \\
\hline
\end{tabular}

Note:

a) Numbers followed by same letter on the same column are not obviously different based on T-test at 5\% significance level

Table 3. Steinhaus Similarity Index on three research sites

\begin{tabular}{|c|c|c|c|}
\hline Phase of Growth & Location & Secondary Forest & Invaded Forest \\
\hline \multirow{2}{*}{ Tree } & Primary Forest & 0.35 & 0.29 \\
\hline & Secondary Forest & - & 0.43 \\
\hline \multirow{2}{*}{ Pole } & Primary Forest & 0.24 & 0.19 \\
\hline & Secondary Forest & - & 0.41 \\
\hline \multirow{2}{*}{ Sapling } & Primary Forest & 0.36 & 0.36 \\
\hline & Secondary Forest & - & 0.35 \\
\hline \multirow{2}{*}{ Seedling } & Primary Forest & 0.24 & 0.13 \\
\hline & Secondary Forest & - & 0.10 \\
\hline
\end{tabular}

Mantangan climbed up the canopy for sunlight, then rapidly grew and covered the entire canopy. The covered trees did not receive enough sunlight and hold the mantangan's weight as well. This condition caused those covered trees gradually died. Another case was that mantangan would twist the trunk so the growing process of the twisted tree would be devastated. However, this case was rarely found.

Mantangan invasion was calculated by percentage estimation of its cover. In the primary forests, the coverage of mantangan was very little with an average of only $1 \%$ and the highest value of coverage was $15 \%$. In the secondary forests, the average coveriage was $27 \%$ and the highest value of coverage was $55 \%$. In addition, the invaded forests were the forests with the highest percentage of mantangan coverage. It reached an average of $44 \%$ coverage. In some locations, they were fully covered by mantangan (100\%) (Figure 2).

Mantangan invasion made possible because of the forest devastation caused by forest fragmentation. Forest fragmentation might occur due to several activities such as illegal logging, farming, and land clearing for road construction. In several invaded forests, there were remnants types of crops that was abandoned for a long time such as dadap (Erythrina variegata) and coffee (Coffea arabica). Moreover, some logged trees were found. It was assumed that this location was a farming area. 
Forest devastation in BBSNP already happened since 1960s. According to satellite image analysis from 1972 to 2006, BBSNP had lost 22\% of its forest cover and left about 67.225 ha of total area 356.800 ha of national parks (Suyadi 2011). Forest devastation in BBSNP was mostly done by the farmers who live in and around the forest (Suyadi 2011). On an invaded forest, there was an enclave that was a district in the administrative area of Way Haru Village, West Lampung Regency. Furthermore, on this location there was a four-meter-dirt road for nature tourism activities and the conservation of Sumatran tigers. The existence of enclave and dirt road in this national park became the causes of forest fragmentation.

Forest fragmentation might cause some impacts, one of which was the edge effect (Watson et al. 2004). Edge effects on forest ecosystem occurred in a form of microclimate changes, species composition changes, the decline of plants diversity, the abundance and density of species. This might cause local extinction of species because they were unable to adapt to the changing of condition there (Meffe 1994). These edge effects became worse with the presence of invasive species, such as mantangan. It was alleged that at the edges of forest fragments, mantangan was able to live well and start invading into the forest. At the edges of open forests, soil moisture would decrease (Sizer 1999). In this condition, a liana like mantangan was able to live better than other trees (Londre 2006).

\section{CONCLUSIONS}

Invasion of mantangan was feared to have an effect on forest regeneration in the future, because in the invaded forest, the number of seedlings was significantly less than the number of saplings, pole and tree. Furthermore, the diversity and number of seedlings was lower than in the two other forests. Hence, it is necessary to do efforts to control the M.peltata invasion in BBSNP.

\section{ACKNOWLEDGMENTS}

This study was part of the master thesis of the first author financially supported by SEAMEO-BIOTROP DIPA 2011 through Dr. Sri S. Tjitrosoedirdjo. The author wishes to thank Artha Graha Peduli and Wildlife Conservation Society Indonesia Program for their facilities in conducting the field works.

\section{REFERENCES}

[BTNBBS] Balai Taman Nasional Bukit Barisan Selatan. 1999. Rencana Pengelolaan Taman Nasional Bukit Barisan Selatan, Buku II. Kota Agung, Lampung: BTNBBS.

Campbell DG, Stone JL, Rosas A Jr. 1992.A Comparison of the Phytosociology and Dynamics of Three Floodplain (Varzea) Forest of Know Ages, Rio Jurua, Western Brazilian Amazon.Bol J of Linnaian Soc 180: 213-37. 
Condit R, Hubbell SP, LaFrankie JV, Sukumar R, Manokaran N, Foster RB, Ashton PS. 1996. Species Area and Species Individual Relationship for Tropical Tree: A Comparison of Three 50-ha Plots. J Ecology 84 : 549-62.

Dyke Fred Van. 2003. Conservation Biology: Foundations, Concepts, Applications. International Edition. New York. USA: McGraw-Hill Companies.

Goldammer JG, B Siebertand, W Schindele. 1996. Fire in Dipterocarp Forest. In: A Schulteand D Schöne, editor. Dipterocarp Forest Ecosystem: Toward Sustainable Management. Singapore: World Scientific.

Irianto R, Tjitrosoedirdjo S. 2010.Invasi Merremia peltata (L.) Merr., Convolvulaceae di Taman Nasional Bukit Barisan Selatan, Indonesia. J Gulma dan Tumbuhan Invasi Tropika 1:65-70.

Lieberman D, Lieberman M, Peralta R, Hartshorn GS. 1996. Tropical Forest Structure and Composition on a Large Scale Altitudinal Gradient in Costa Rica. J Ecology 84: 137-52.

Londre RA, Schnitzer SA. 2006. The distribution of Lianas and their change in abundance in temperate forests over the past 45 years. J Ecology 87:2973-8.

Meffe GK, Carrol CR. 1994. Principles of Conservation Biology. Sunderland: Sinnauer Assoc.

Pascal JP, Pelissier R. 1996. Structure and floristic composition of a tropical evergreen forest in Southwest India. J Trop Ecol 12: 191-214.

Prasetyo A, Hikmat A, Prasetyo LB. 2011. Pendugaan perubahan cadangan karbon di tambling wildlife conservation taman nasional bukit barisan selatan. Media Konservasi 16:87-91.

Purwaningsih. 2009. Analisis vegetasi hutan riparian dataran rendah di tepi Sungai Nggeng, Taman Nasional Kayan Mentarang, Kalimantan Timur. Berita Biologi 9 : 254-9.

Sheil D, Ducey MJ, Sidiyasa K, Samsuddin I. 2002. A new type of sample unit for the efficient assessment of diverse tree communities in complex forest landscapes. Bogor: CIFOR.

Sizer N, Tanner EVJ. 1999. Response of woody plant seedlings to edge formation in lowland tropical rainforest, Amazonia. Biol Conserv 91: 135-42.

Smith AC. 1991. Flora Vitiensis Nova. Volume 5, Lawai, Kauai, Hawai'i, National Tropical Botanical Garden. 49 50.

Suyadi. 2011. Deforestation in Bukit Barisan Selatan National Park, Sumatre, Indonesia. J Biol Indonesia 7: 195206.

Watson JEM, Whittaker RJ, Dawson TP. 2004. Effects of deforestation and forest modification on understorey bird in Central Sulawesi, Indonesia. Bird Conserv Int 15:257-73.

[WCS-IP] Wildlife Conservation Society - Indonesia Program. 2001. Taman Nasional Bukit Barisan Selatan dalam ruang dan waktu. Laporan Hasil Penelitian 2000 - 2001. Bogor: PHKA/WCS-IP. 